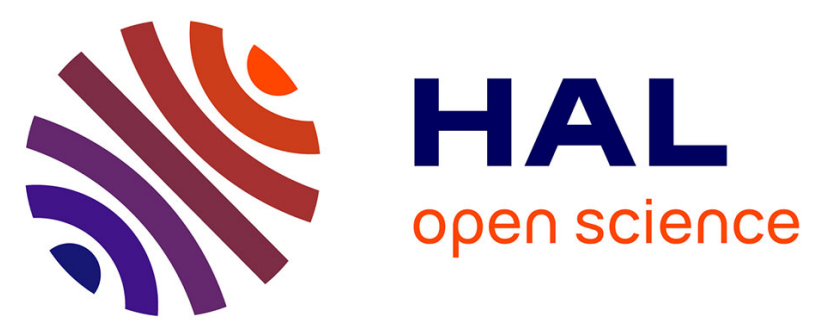

\title{
Effects of water-level fluctuations on the environmental characteristics and fish-environment relationships in the littoral zone of a reservoir
}

Maxime Logez, Romain Roy, Laurence Tissot, Christine Argillier

\section{- To cite this version:}

Maxime Logez, Romain Roy, Laurence Tissot, Christine Argillier. Effects of water-level fluctuations on the environmental characteristics and fish-environment relationships in the littoral zone of a reservoir. Fundamental and Applied Limnology, 2016, 189 (1), pp.37-49. 10.1127/fal/2016/0963 . hal-01444027

\author{
HAL Id: hal-01444027 \\ https://hal.science/hal-01444027
}

Submitted on 14 Feb 2022

HAL is a multi-disciplinary open access archive for the deposit and dissemination of scientific research documents, whether they are published or not. The documents may come from teaching and research institutions in France or abroad, or from public or private research centers.
L'archive ouverte pluridisciplinaire $\mathbf{H A L}$, est destinée au dépôt et à la diffusion de documents scientifiques de niveau recherche, publiés ou non, émanant des établissements d'enseignement et de recherche français ou étrangers, des laboratoires publics ou privés. 


\title{
Effects of water-level fluctuations on the environmental characteristics and fish-environment relationships in the littoral zone of a reservoir
}

\author{
Maxime Logez, Romain Roy, Laurence Tissot and Christine Argillier
}

With 8 figures and 2 tables

\begin{abstract}
Water-level fluctuations are a major function of reservoirs that influence the littoral zone of the lake, and prove to be of high importance for the whole biological communities of lakes. Working on a French hydropower reservoir, we studied the influence of water-level fluctuations on intra-annual variations of littoral habitat availability and their consequences for the structure of fish assemblages inhabiting the littoral zone. As the water level decreased significantly, habitat conditions tended to be much more homogeneous. The proportion of sites with a thin substrate and low slope increased, while submerged vegetation and riparian shade disappeared. The relationship between habitat complexity and fish assemblage changed along the water-level gradient. The habitat effect on assemblage structure was strongest when the water-level conditions were high and very high, and weaker for low and very low water-level conditions. A homogenization of fish assemblages was observed when the water-level condition reached a threshold. These results suggest an effect of water-level management in structuring fish assemblages of the littoral zone of a reservoir due to a decrease of habitat complexity.
\end{abstract}

Keywords: reservoir; littoral zone; habitat; fish; water-level fluctuations

\section{Introduction}

Reservoirs are being continuously built worldwide as a consequence of the increase in human needs and their activities. The impacts of reservoirs on river ecosystems have been relatively well documented, especially in terms of changes in morphology, connectivity loss and flow regulation (Falke \& Gido 2006; Nilsson et al. 2005; World-Commission-on-Dams 2000). Similarly, the dynamics of physical and chemical characteristics of impounded waters, and the development of their biological communities following dam construction, have been described previously (Freedman et al. 2014). However, considering the economic motives for dam construction generally prevail, far less attention is paid to the ability of these reservoirs to maintain sufficient environmental conditions to support sustainable biological communities (Jager \& Smith 2008). Considering the current increasing concern for the environmental objectives assigned to the European water bodies, whatever their origin and uses, managers are starting to pay more attention to the effects of water use on reservoir biological communities.

From a hydrological point of view, reservoirs function in a way intermediate between rivers and lakes. They are highly dependent on human needs, resulting in irregular and sometimes extreme variations in water level (Wetzel 1990). The hydrologic variability in 
terms of water level fluctuations (WLFs) have to be considered as strong drivers for biota inhabiting these reservoirs (European Union 2000). Indeed, because they are interfacing aquatic and terrestrial systems, littoral zones have a greater heterogeneity of physical structure (Schmieder 2004; Zohary \& Ostrovsky 2011), habitat diversity, and greater trophic resources than pelagic areas (Pierce, Rasmussen \& Leggett 1993). Consequently, the littoral zone of reservoirs is crucial for the functioning of the biological cycle of many species and provides shelter for a high biodiversity (Keast 1985; Savino \& Stein 1989; Werner et al. 1977). Thus, even if the natural pattern of WLFs can be considered to enhance the productivity and biodiversity of aquatic ecosystems in some conditions (Gafny \& Gasith 1999; Wantzen et al. 2008), extreme and untimely water-level fluctuations are often considered as the main hydrological stressor for communities inhabiting the littoral area of reservoirs (Sutela \& Vehanen 2008).

Numerous studies have been aimed at determining the impacts of WLFs on biological communities of standing waters. However, the effort does not seem to have been consistent for all organism groups, with ichthyofauna the least studied group (Leira \& Cantonati 2008). For fish, most of the studies have stressed the impacts of WLFs on species reproduction. Even if this phenomenon has not been well described and quantified in the literature, it can be stated that drops in water level can induce mortality of dewatered eggs. In addition, it was shown that reproductive success and/or the year-class strength of different species can be impacted (Kahl et al. 2008; Ostrovsky \& Walline 2000; Webb 2008). However, these results could be highly dependent on the hydrological regime of the lakes and of species traits and vulnerability (Emmrich et al. 2014; James \& Graynoth 2002). Although less studied, the littoral zone offers shelters for fish in which habitat availability is liable to fluctuate with WLFs, thus inducing a particular fish behavioral response (Fischer \& Ohl 2005; Gafny et al. 1992).

In spite of the interest in understanding the impact of hydrological constraints on the relationships between fish species, little is known about the consequences of the water-level changes on fish assemblages. In some conditions, the lowering of the water level was considered as responsible for changes in characteristics of the littoral fish communities (Paller 1997). Conversely, other scientists have failed in showing a clear and consistent pattern between water level and the littoral fish assemblages (Sutela \& Vehanen 2008; Webb 2008).
The present study is dedicated to a better understanding of the impact of water level on the habitat. The link between habitats and fish assemblages of the littoral zone of reservoirs in the context of WLFs is considered. We expected an initial decrease in habitat complexity, then a subsequent homogenization of the fish communities in relation with the habitat loss. The results obtained could then be put to use in an improved consideration of fish assemblages in the hydraulic management of reservoirs. The changes in habitat characteristics induced by WLFs were first analyzed in a highly monitored reservoir. In the same reservoir, fish-habitat relationships were then explored for four different hydrological conditions.

\section{Material and methods}

\section{Study site}

Bariousses reservoir is located in the upper part of the Vézère River in West-Central France, at an altitude of $516 \mathrm{~m}\left(45.33^{\circ} \mathrm{N}\right.$, $1.49^{\circ} \mathrm{E}$ ) (Fig. 1), was built in 1951, and is operated by Electricité De France (EDF). The reservoir has an area of 80.9 ha, a perimeter of $9.9 \mathrm{~km}$, and mean and maximum depths of $7.1 \mathrm{~m}$ and $18.9 \mathrm{~m}$, respectively. The reservoir's volume is $5,707,290 \mathrm{~m}^{3}$, with a mean renewal time of twelve days. The reservoir is monomictic with a period of summer stratification.

The Bariousses reservoir displays a large heterogeneity of water levels depending of the season. In summer, the water level is relatively stable to support touristic activities (fluctuations less than $0.5 \mathrm{~m}$ ), but in September, the water level usually decreases in anticipation of autumn rains and floods. In 2011, the water level fluctuated within an altitudinal range of 507.2 to $513.5 \mathrm{~m} \mathrm{NgF}$ with a mean of $511 \mathrm{~m} \mathrm{NgF}$ (Fig. 2). This amplitude fluctuation is regularly observed at the inter-annual scale (EDF, personal source). The reservoir is located in a rural and natural environment, in a catchment dominated by forest land cover with low anthropogenic activities.

\section{Fish sampling procedure}

Thirty sampling sites throughout the reservoir were selected to represent the habitat diversity of the littoral zone. They were characterized by $45 \mathrm{~m}$ of shoreline (measured by the Euclidian distance between two GPS points) with homogenous characteristics of the habitat $(46.7 \pm 14 \mathrm{~m})$, i.e., with similar slope, substrate, vegetation and shade. Together, the sampling sites represented $14.5 \%$ on average $(13.7-15.4 \%)$ of the total shoreline. The sites had a similar (Gelwick \& Matthews 1990) depth of between 0 and $1.5 \mathrm{~m}$ to maximize the efficiency of electrofishing (Brosse et al. 2007, Gelwick \& Matthews 1990).

Fish were sampled at four dates corresponding to different water level conditions: 19-21 July 2011 (511.64 $\pm 0.07 \mathrm{~m}$ and named very high or VH), 23-25 August 2011 (511.38 $\pm 0.07 \mathrm{~m}$ and named high or H), 20-22 September 2011 (510.15 $\pm 0.01 \mathrm{~m}$ and named low or L) and 18-20 October 2011 (508.98 $\pm 0.06 \mathrm{~m}$ and named very low or VL) during daylight hours by electrofishing (Fig. 2). Transparency did not significantly change during these four dates; it was measured at between 1.8 and $2.2 \mathrm{~m}$ with a Secchi disk. 


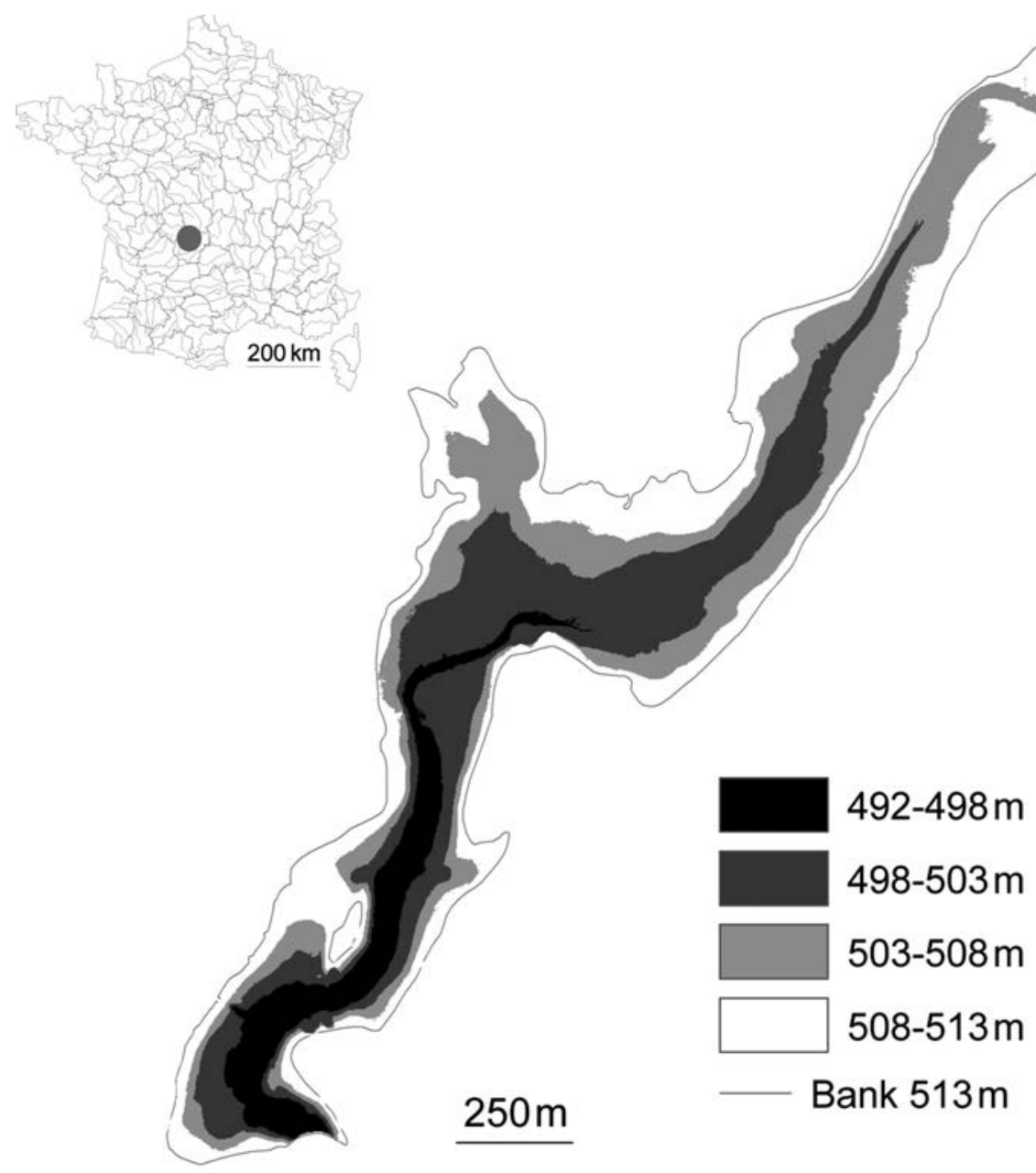

Fig. 1. Location of the Vézère River in France and map of the Bariousses reservoir with altitudinal contour lines.

A boat was equipped with an electro-fisher (EFKO FEG 8000 , Germany) using a continuous voltage between 300 and $600 \mathrm{~V}$. A total of 120 samples $(30$ sites $\times 4$ water level conditions) were collected. Fish species caught were determined and the individuals of each species were classified into two "ecospecies", representing either young-of-the-year (hereafter referred to as juveniles) or older fish (hereafter referred to as adults), depending on their size (Brosse et al. 2007). Fish samples were characterized by the presence/absence of all the ecospecies collected.

\section{Environmental characterization}

Each sampling site was described just after the fish sampling using nine environmental variables (six categorical and three numeric). The substrate was characterized according to the Cailleux \& Tricart (1959) classification and then categorized into "thinner" $(<2 \mathrm{~mm})$ (Thin) and "coarser" $(>2 \mathrm{~mm})$ (Coarse) groups. Vegetation was categorized by four variables: the presence of submerged vegetation (tree branches, flooded grasses, and helophytes) (SV), absence of submerged vegetation (NSV), presence of riparian shade (Shade) and absence of riparian shade (Light) (Broadmeadow et al. 2010; Gelwick \& Matthews 1990). Dominant submerged vegetation was composed of spe- cies of the genus Quercus, Alnus, Juncus and Carex. Vegetation was noted as "present" when it was observed in more than $50 \%$ of the sampling area. The sampling period matched the development of both aquatic and terrestrial vegetation. Slope was classified into three classes, i.e., low (Lslo), medium (Mslo), and high (Hslo), whereas depth (D) was described by an average value over the whole sampling site. Surface temperature (Temp) and oxygen concentration $\left(\mathrm{O}_{2}\right)$ were also collected during the sampling (WTW Oxi 197i).

\section{Data processing}

The data set was composed of 120 samples, with 30 stations sampled at the four water level conditions: VH, H, L and VL. Both environmental and biological data were collected for each water level. Different analyses were performed depending on the aim pursued.

First, a "mixed" analysis (Hill \& Smith 1976) to assess the link between the environmental variables at each water level was conducted, which is a one-table analysis that handles both quantitative and qualitative data. It is equivalent to a principal component analysis on a correlation matrix when only quantitative variables are used, and is equivalent to a multiple correspondence analysis when only qualitative variables are used. 


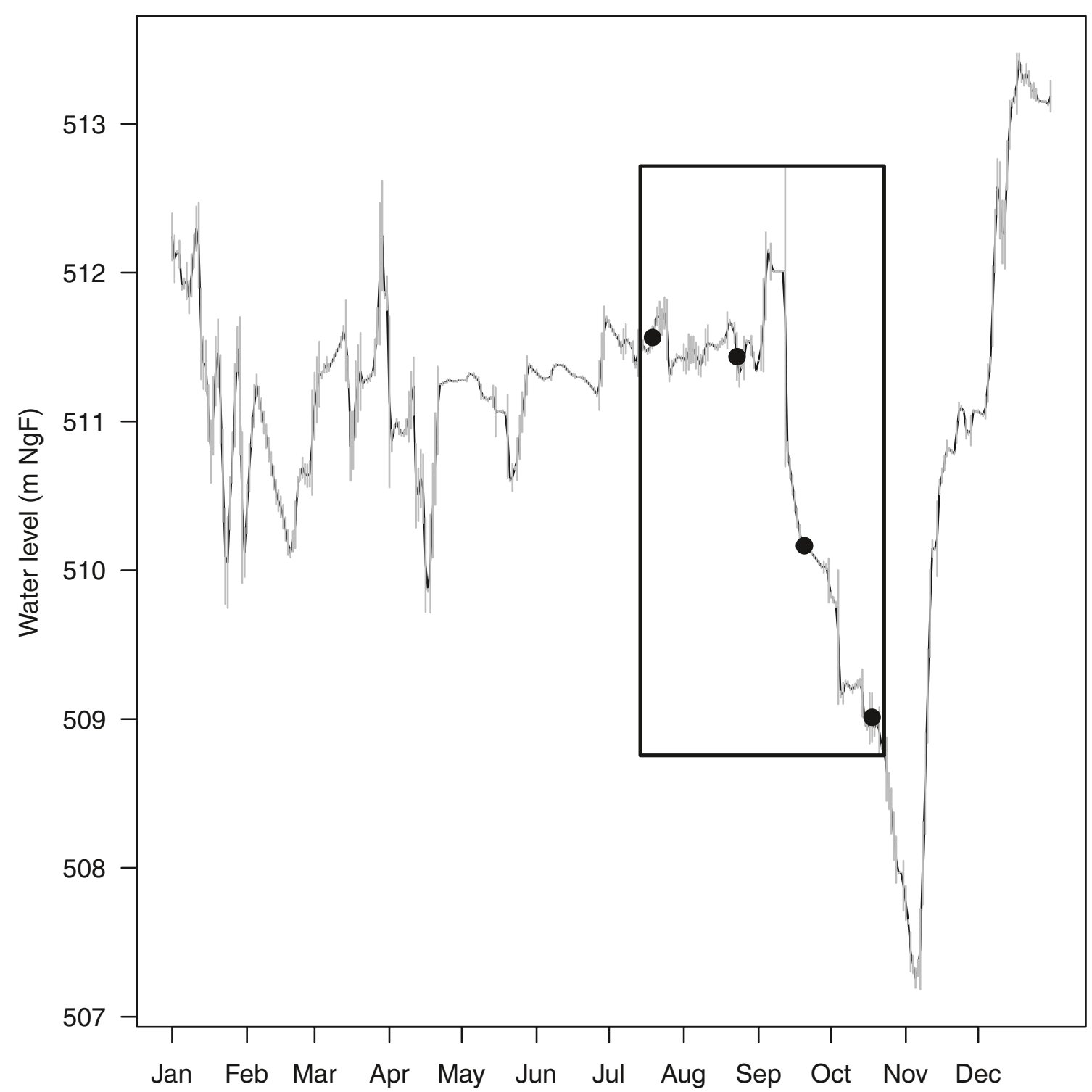

Fig. 2. Water-level fluctuations in the Bariousses reservoir in 2011 (daily average \pm 2 SD), water level during study period (black frame), and water level during samplings (black dots).

To assess at which water level the environmental conditions were the most similar (and on the contrary the most divergent), the global trend of the link between the environmental conditions were then performed with a STATIS analysis (Lavit et al. 1994). STATIS is a k-table analysis, which first estimates the link between the different tables of two by two (the four environmental tables collected at each water level) through RV coefficients (Robert \& Escoufier 1976). This coefficient extends the correlation coefficient to two tables. The RV matrix is then decomposed (similarly to a PCA with the matrix of correlation) and each table is ordered on a factorial map (correlation circle) corresponding to the interstructure. The interstructure gives an image of the similarity among tables. The common pattern typology is established among the tables by weighting and "averaging" the tables. The synthetic covariance matrix is diagonalized and the compromise could be analyzed as any multivariate analysis, as the generated axes are linear combinations of the columns (environmental variables). The original table (of each water level) could then be projected on the compromise space; the intrastructure is used to assess the internal variability. Analysing the compromise and the intrastructure could be compared with the analysis of the means and the variance of a set of tables. The interstructure, compromise and intrastructure are the three major results of a k-table analysis, whatever the analysis performed (STATIS, PTA, etc.). The relationships between habitat conditions and fish were first analyzed at each water level using a coinertia analysis (Doledec \& Chessel 1994; Dray et al. 2003). This statistical analysis is designed to study the link between two tables (environment and fish) paired by their lines (sites). In contrast to a method such as RDA, this analysis is symmetric without a given table explaining the variability of the second one. Coinertia searches for common axes that maximize the covariance between the factorial axes of the two separated analyses of the environment table and the fish ta- 
ble. The magnitude of the link between fish and habitat at each water level was measured by an RV coefficient that was tested using a permutation test (Heo \& Gabriel 1994).

Finally, the STATICO analysis was used to seek for fishhabitat similarities among water levels (interstructure), the common typology between the fish-habitat relationships (compromise), and the possible variability between fish-habitat relationships at the various water levels (intrastructure). STATICO, as STATIS, is a k-table analysis.

All calculations and graphics were made using the R. software (R Development Core Team 2008) and the ade4 package (Dray et al. 2007).

\section{Results}

\section{Characterization of the littoral habitats}

The water level decreased over the sampling period, first slightly between $\mathrm{VH}$ and $\mathrm{H}(-0.26 \mathrm{~m})$, and then faster $(-1.23 \mathrm{~m}$ between $\mathrm{VH}$ and $\mathrm{L}$ and $-1.17 \mathrm{~m}$ between L and VL) (Fig. 2). The habitat conditions of the littoral zone changed along the water level gradient (Table 1). The highest variations between the sampling periods concerned the abundance of coarse substrate, submerged vegetation and shade.

Environmental conditions at $\mathrm{VH}$ and $\mathrm{H}$ were very similar as shown by their proximity to the correlation circle of the STATIS inter-structure (Fig. 3a), while the most singular environmental conditions were observed at L (Fig. 3a). The compromise (Fig. 3b), the "average typology" of environmental conditions, revealed that the slope, substrate, shade and depth composed the main gradient of habitat conditions among sites. The first axis of the compromise opposed deep sites with riparian shade, high or moderate slope, and coarse substrate to shallow sites with no riparian shade, low slope and a thin substrate (Fig. 3b).

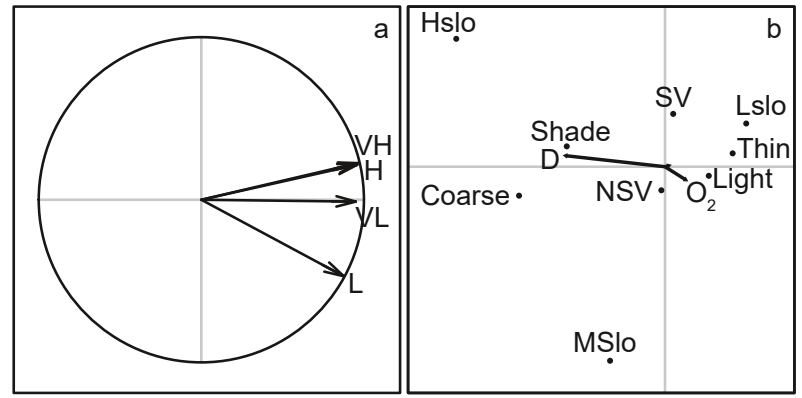

Fig. 3. Results of the STATIS analyses (axis 1 on $x$-axis and axis 2 on y-axis) carried out on four environmental tables, one for each water-level condition: very high, high, low and very low. a) inter-structure, b) compromise (abbreviations are listed in Table 1). Temp was not represented due to its low contribution to the first factorial plan.

Littoral habitat conditions became gradually more homogeneous along the water level, decreasing as revealed by the intra-structure (ordination of sites based on their environmental conditions at each water level). During L and VL water levels, site locations were concentrated in restricted areas of the first factorial plan, while site locations were highly dispersed at $\mathrm{H}$ and $\mathrm{VH}$ water levels (Fig. 4). Moreover, when the water level decreased, the proportion of sites with a thin substrate and a low slope increased, while submerged vegetation and riparian shade disappeared (Figs 3,4), confirming the general tendency showed on Table 1.

Some sites experienced significant changes along the water level decrease as revealed by their long trajectories (site locations successively linked from VH to VL) along water-level conditions (Fig. 5). Sites moving from the left side of the factorial plan toward the right side (sites 1, 2, 7, 17, 22, 23, 24 and

Table 1. Environmental characteristics observed in the 30 sampling sites of the littoral zone during the sampling period described by number of sites for each of the categorical parameters (Lslo, Mslo and Hslo - respectively low, medium and high slope; Thin and Coarse - respectively thin and coarser substrate; SV - presence of submerged vegetation; Shade - presence of riparian shade) and by values for each numerical variables (Temp - surface temperature; $\mathrm{O}_{2}$ - oxygen concentration; $\mathrm{D}-\mathrm{depth}$ ) (in italic, mean $\pm \mathrm{SD}$ ).

\begin{tabular}{lcccc}
\hline $\begin{array}{l}\text { Environmental } \\
\text { characteristics }\end{array}$ & VH & H & L & VL \\
\hline Lslo & 15 & 17 & 17 & 22 \\
Mslo & 9 & 7 & 8 & 5 \\
Hslo & 6 & 6 & 5 & 3 \\
Thin & 15 & 18 & 25 & 24 \\
Coarse & 15 & 12 & 5 & 6 \\
SV & 16 & 21 & 0 & 0 \\
Shade & 13 & 18 & 2 & 4 \\
Temp $\left({ }^{\circ} \mathrm{C}\right)$ & $18.0 \pm 0.4$ & $24.5 \pm 0.7$ & $16.4 \pm 1.6$ & $19.7 \pm 0.9$ \\
$\mathrm{O}_{2}\left(\mathrm{mg} \mathrm{L}^{-1}\right)$ & $9.7 \pm 0.4$ & $8.5 \pm 0.3$ & $8.6 \pm 0.8$ & $8.8 \pm 0.5$ \\
$\mathrm{D}(\mathrm{m})$ & $0.7 \pm 0.4$ & $0.7 \pm 0.3$ & $0.7 \pm 0.3$ & $0.6 \pm 0.2$ \\
\hline
\end{tabular}




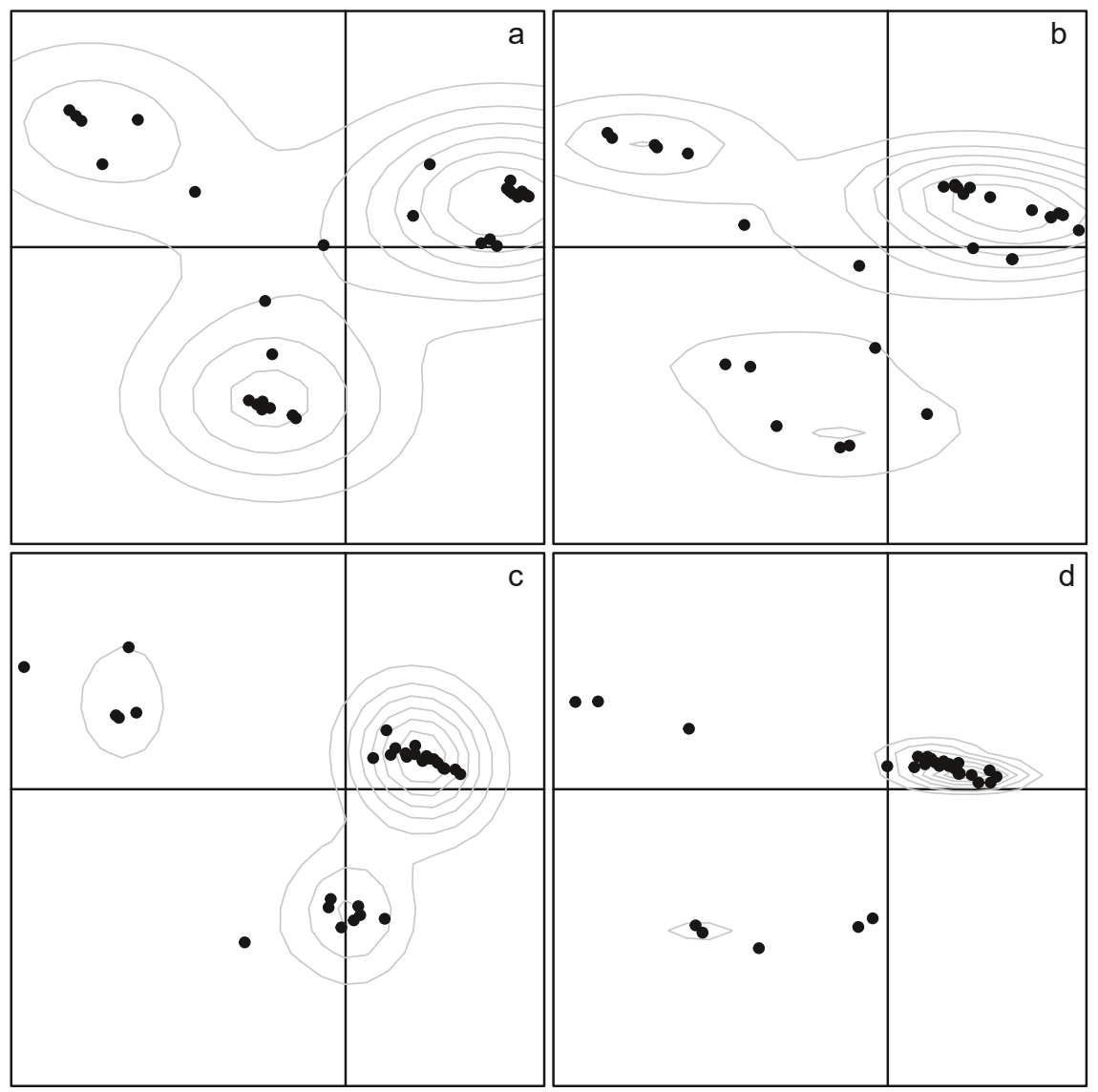

Fig. 4. First factorial plan (axis 1 on $\mathrm{x}$-axis and axis 2 on y-axis) of the STATIS intra-structure carried out on four environmental tables, one for each water level condition: a) very high, b) high, c) low and d) very low. Lines are 2 D-kernel estimations of the density of points.

30; Fig. 5) experienced a decreasing slope, depth and substrate size, but also the disappearance of riparian shade. Nevertheless, some sites had relatively short trajectories, suggesting stable habitat conditions for a thin substrate and a low slope (sites 4, 8, 10,11, 12, 14, 18 and 26; Fig. 5), or coarse substrate with high slope (sites 15, 25 and 28; Fig. 5), regardless of the water level.

\section{Relationships between environmental conditions and fish assemblages}

Seven species representing ten ecospecies, four juveniles and six adults, with an occurrence greater than $5 \%$ were sampled (Table 2 ).

Pumpkinseed Lepomis gibbosus L. (juvenile and adult), adult perch Perca fluviatilis L., and juvenile

Table 2. Occurrence of each ecospecies among the sampling sites for each of the water-level conditions. The common name is followed by the Latin name and abbreviation in brackets.

\begin{tabular}{|c|c|c|c|c|c|}
\hline Ecospecies & VH & $\mathbf{H}$ & $\mathbf{L}$ & VL & Pooled \\
\hline Adult pumpkinseed (Lepomis gibbosus L.) (APu) & 33.3 & 33.3 & 13.3 & 20.0 & 25.0 \\
\hline Adult perch (Perca fluviatilis L.) (APe) & 30.0 & 23.3 & 20.0 & 20.0 & 23.3 \\
\hline Adult roach (Rutilus rutilus L.) (ARo) & 16.7 & 13.3 & 6.7 & 3.3 & 10.0 \\
\hline Adult rudd (Scardinius erythrophthalmus L.) (ARu) & 6.7 & 16.7 & 26.7 & 20.0 & 17.5 \\
\hline Adult wels catfish (Silurus glanis L.) (AWe) & 13.3 & 26.7 & 6.7 & 10.0 & 14.2 \\
\hline Adult chub (Squalius cephalus L.) (ACh) & 6.7 & 6.7 & 3.3 & 6.7 & 5.8 \\
\hline Juvenile freshwater bream (Abramis brama L.) (JBr) & 3.3 & 13.3 & - & 3.3 & 5.0 \\
\hline Juvenile pumpkinseed (Lepomis gibbosus L.) (JPu) & 13.3 & 36.7 & 46.7 & 43.3 & 35.0 \\
\hline Juvenile perch (Perca fluviatilis L.) (JPe) & - & 13.3 & 10.0 & 3.3 & 6.7 \\
\hline Juvenile rudd (Scardinius erythrophthalmus L.) (JRu) & 20.0 & 46.7 & 36.7 & 10.0 & 28.3 \\
\hline
\end{tabular}




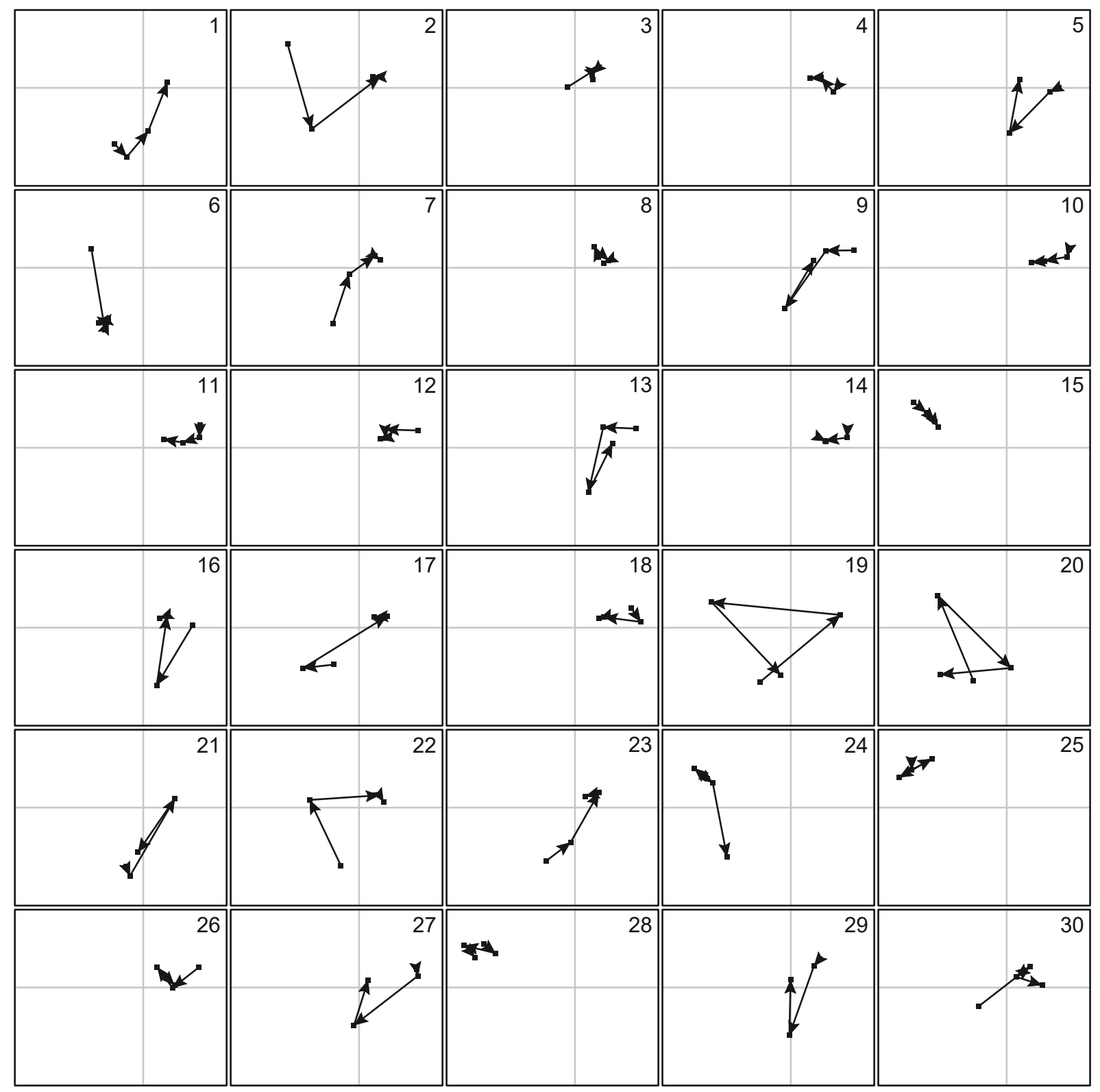

Fig. 5. Intra-structure of the STATIS analyses (axis 1 on x-axis and axis 2 on y-axis) carried out on four environmental tables with the trajectories of sites by projecting the four tables on the compromise space. The start point of the arrow is for site conditions at very high water levels and the end point of the arrow is for site conditions at the very low water level.

rudd Scardinius erythrophthalmus L., were the most frequently observed ecospecies. However, eight ecospecies with an occurrence lesser than $5 \%$ were sampled: adult ruffe Gymocephalus cernua L. (ARuf), European brook lamprey Lampetra planeri B. (ALa), brown trout Salmo trutta L. (ATr), bream Abramis brama L. (ABr), and juvenile pike Esox lucius L. (JPi), roach Rutilus rutilus L. (JRo), ruffe Gymocephalus cernua L. (JRuf), wels catfish Silurus glanis L. (JWe). The highest occurrence variations between the sam- pling periods concerned the adult and juvenile pumpkinseed, and rudd and adult wels catfish (Table 2).

The RV coefficient, measuring the strength of the link between the environmental and fish tables sampled at each water-level condition, was the highest for $\mathrm{H}(0.445, p<0.01)$ followed by $\mathrm{VH}(0.308, p<0.01)$, $\mathrm{L}$ $(0.245, p<0.05)$ and VL $(0.231, p<0.05)$.

Equivalently to the habitat conditions (STATIS), the relationships between habitat conditions and fish assemblages (STATICO) were fairly similar between 


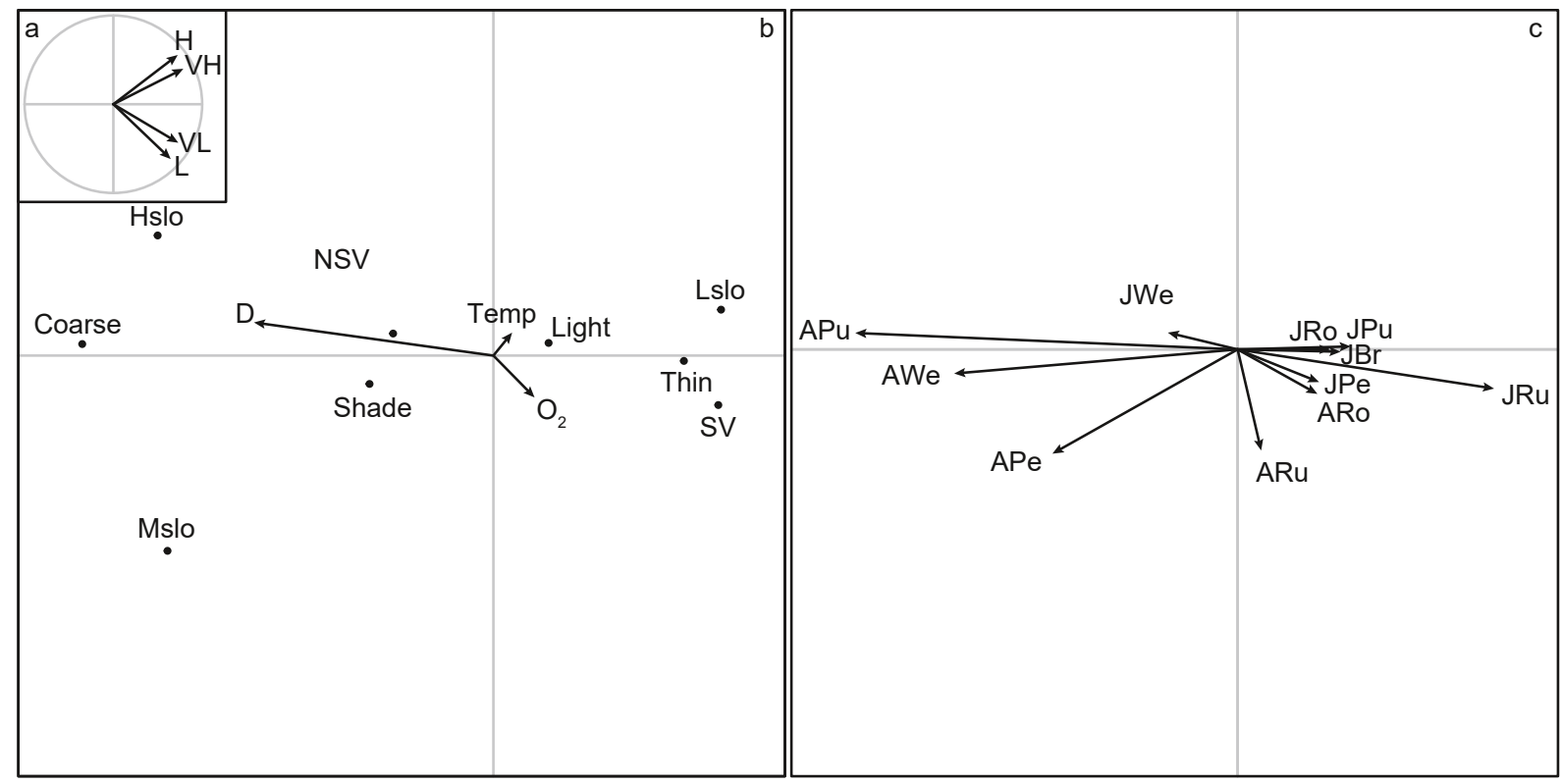

Fig. 6. Results of the STATICO analyses (axis 1 on $\mathrm{x}$-axis and axis 2 on y-axis) carried out on the four co-inertia analyses between environment and fish tables, at each water level: very high, high, low and very low. a) inter-structure, b) compromise of the STATICO analysis for habitat characteristics, c) the compromise of the STATICO analysis for ecospecies.

the two highest water-level conditions and relatively different from those observed at $\mathrm{L}$ and $\mathrm{VL}$ water levels (Fig. 6a). The most singular pattern was also observed for the $\mathrm{L}$ water-level condition. The common typology obtained with the STATICO compromise showed that ecospecies were on average distributed along gradients of substrate size, slope, depth and submerged vegetation on the first axis and by riparian shade on the second axis (Fig. 6b,c). The first axis of the compromise consisted of globally separated juveniles from adults (Fig. 6c), juveniles occurring mostly in low slope conditions with a thin substrate and low depth, and submerged vegetation but without riparian shade. On the other hand, adults occurred in deeper environments with moderate to high slopes, coarser substrates with an absence of submerged vegetation, but with riparian shade. Two ecospecies, adult road and rudd, occurred rather with juveniles.

The main effect of substrate size, slope and riparian shade was observed at each water-level condition as revealed by the intra-structure of the STATICO analysis (variability between each water level). These variables were present on each factorial plan corresponding to each water level projected on the compromise space (Fig. 7a-d). Despite this general pattern, the intrastructure revealed a large variation of the main environmental drivers among water-level conditions (Fig. 7). While submerged vegetation was an important environmental driver for the two highest water- level conditions (located on the edge of the first axis) $\mathrm{VH}$ and $\mathrm{H}$, this did not shape fish assemblages at the L. and VL water-level conditions. Moreover, the depth influence on species assemblage seemed more important at the highest water level (longer arrow), whereas oxygen concentration only appeared to structure fish assemblages at low water-level conditions.

General patterns concerning ecospecies distribution arose from intrastructure outputs, confirming the average typology observed on the compromise (Fig. 8). Therefore, whatever the water-level condition, adult pumpkinseeds, adult wels catfishes, adult perchs and juvenile rudds, seemed to occur in similar environmental conditions as revealed by their relative stable location on each factorial map of the intrastructure (Fig. 8a-d). Similarly, Figure 8 revealed ontogenic shifts of habitat uses for perch as shown by the separate ordinations of juveniles and adults on the first factorial plan.

Nevertheless, as for abiotic conditions, important variations of habitat use among water levels were observed for some ecospecies. Compared with $\mathrm{H}$ and $\mathrm{VH}$ water-level conditions, ecospecies ordinations were much more regrouped along the first axis at $\mathrm{L}$ and $\mathrm{VL}$ water level conditions, suggesting an homogenization of fish assemblages when water level reached a threshold (Fig. 8c,d). Moreover, some ecospecies as juveniles, as well as adults of pumpkinseed and rudd, that occurred in contrasting habitats for the two high- 


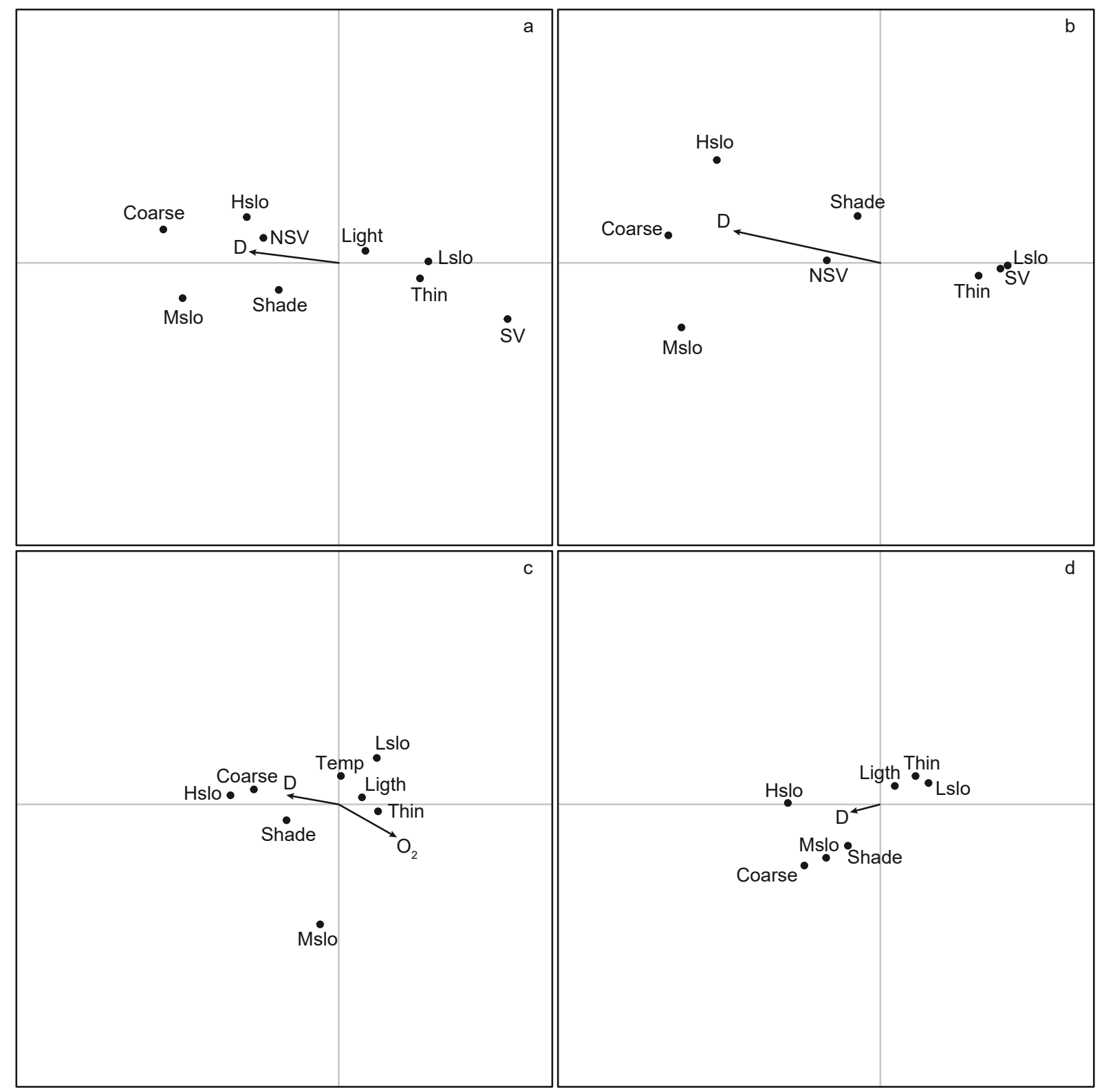

Fig. 7. First factorial plans (axis 1 on x-axis and axis 2 on y-axis) of the intra-structure of the STATICO analysis for environment conditions at each water level. a) very high, b) high, c) low and d) very low. Temp was not represented as non-informative.

est water-level conditions, were distributed in similar habitats at the L water-level condition (Fig. 8a-c).

\section{Discussion}

In confirming our hypotheses, this study shows that the habitat composition changes along WLFs which, in turn, influence the relationship between habitat complexity and fish assemblage. In accordance with the literature, the habitat conditions of the Bariousses littoral zone tended to be much more homogeneous as the water level decreased, with some habitats even disappearing.

Open areas with a fine substrate provide a low structural complexity and no refuge, while a coarse substrate provides intermediate complexity, and habitats with vegetation are known to have a greater diversity of life forms due to their higher complexity (Brauns et al. 2008; Gasith \& Gafny 1998; Meerhoff et al. 2007; Zohary \& Ostrovsky 2011). Together, these habitats generate diverse levels of structural complexity (Dembski et al. 2008; Gasith \& Gafny 1990). In the Bariousses reservoir, the complex habitats were 


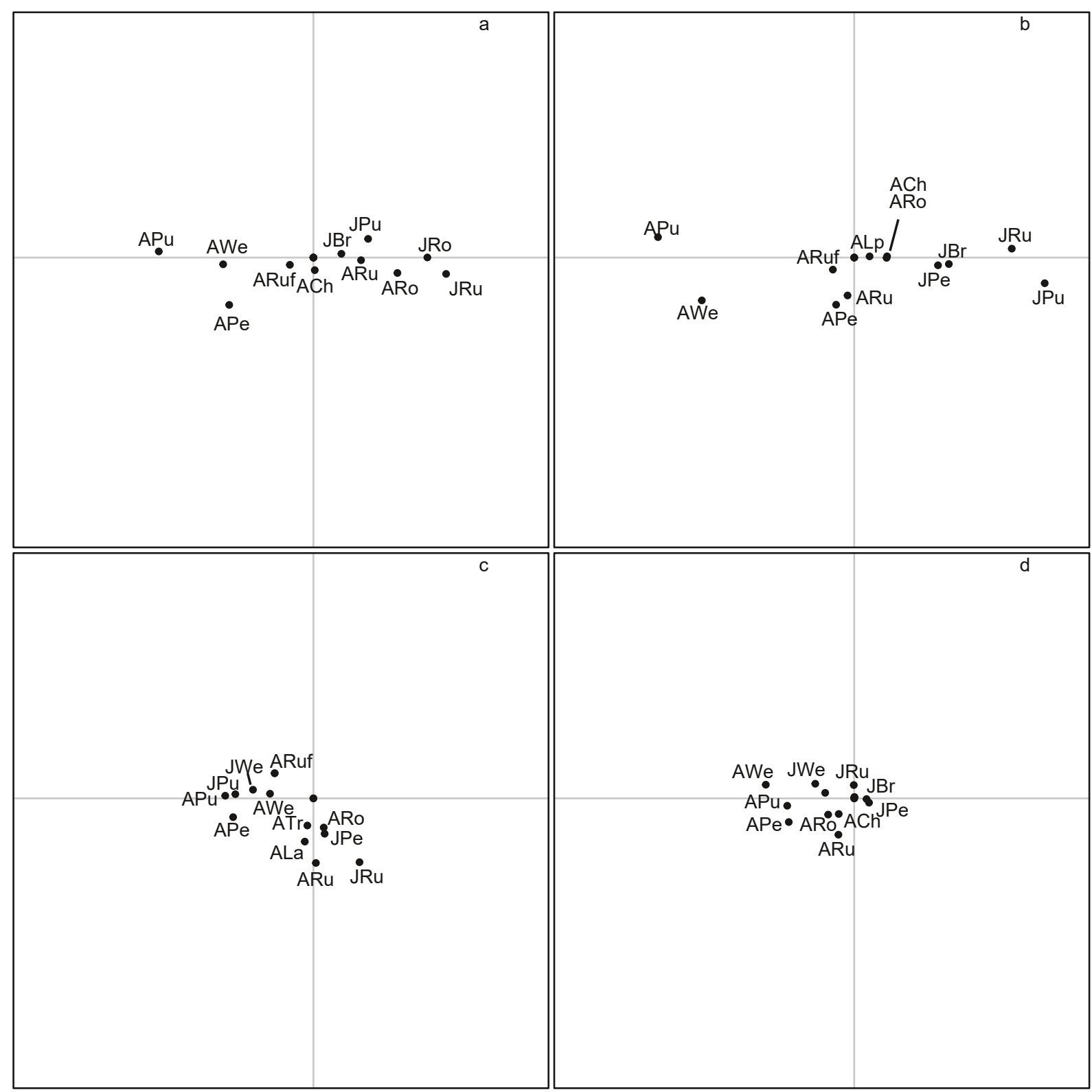

Fig. 8. First factorial plans of the intra-structure of the STATICO analyses for ecospecies, one for each water-level condition. a) very high, b) high, c) low, d) very low.

mainly available for fish during the highest waterlevel conditions. When the water level decreased, some major habitats were lost and the majority of the habitats were composed of thin substrate with a low slope without submerged vegetation and riparian shade. Such habitat homogenization was also observed in Lake Kinneret, a natural lake where the percentage of shoreline covered by small particles increased from $6 \%$ to $49 \%$ with a $3-\mathrm{m}$ decrease in water level (Beauchamp et al. 1994; Gasith \& Gafny 1990; Zohary \& Ostrovsky 2011). Conjointly with the increase in thin substrate, the proportion of coarse substrate declined, and thus also littoral habitat complexity. However, in our study site, the decrease in diversity of the littoral habitats is not proportional to the decrease of the water level. Indeed, the habitat complexity is low but stable between September and October, i.e., level L and VL. This suggests the existence of a kind of threshold corresponding to the stability of habitat characteristics beyond a certain range to the highest shoreline level. Moreover, we have to note that despite a sharp decline in habitat complexity with a drop in water level, few isolated sites of coarse substrate and high slope, corresponding with 
an intermediate structural complexity, were consistently present in the Bariousses reservoir. These sites were the only source of refuge available for fish in the two low water-level conditions. Nevertheless, exposure of new thin substrate during low-water periods facilitated the expansion of emergent plants (Gasith \& Gafny 1990; Hudon 1997; Leira \& Cantonati 2008) available as refuges and foraging habitat for juvenile fish when the water level rose (Dembski et al. 2008; Eklöv 1997; Midwood \& Chow-Fraser 2012; Rozas \& Odum 1988; Savino \& Stein 1989).

Concurrently with these physical modifications, the robust statistical approach implemented here showed that the relationship between habitat complexity and fish assemblage was pronounced and that it changed along a water-level gradient. RV coefficients, as correlation coefficients, could not be directly compared two by two (the samples were not exactly the same), but give a valuable estimation of the strength of the relationships between the environment and biota. For the four water-level conditions studied, the habitat effect on assemblage structure was strongest when the water level was high and very high, whereas a homogenization of fish assemblages was observed once the water level reach a low and very low level. Finally, habitat complexity seems to be an important factor structuring littoral assemblages as predicted by the habitat templet (Southwood 1977; Townsend \& Hildrew 1994), resulting in different assemblages in the different parts of the littoral area of the reservoirs when habitat complexity is high. Conversely, following the lowering of the reservoir water level, the littoral zone offers a poorer diversity of habitat conditions that would result in the homogenization of the fish assemblages, which could result in a modification of the biotic relationships.

In addition, we showed that juveniles of freshwater bream, pumpkinseed, perch and rudd occurred more frequently in the sunny beach area (low slope conditions with thin substrate and low depth) with submerged vegetation. This habitat offers refuge from predatory fish and a maturation area with a high growth rate because of the highest water temperature compared with the other part of the reservoir (Dembski et al. 2008; Rossier 1995; Schmieder 2004). Moreover, adult roach and rudd occurred often in the exposed beach area to take advantage of higher feeding resources (Schmieder 2004), and they were often in shoal of several individuals. On the other hand, adults of pumpkinseed, wels catfish and perch carried out feeding and foraging resources in deeper environments with riparian shade, moderate to high slopes and coarse substrates. Nevertheless, further investigations on diet analysis, growth assessment and predatory risk (Werner et al. 1983a; Werner et al. 1983b) would be necessary to better understand why these species were found in different habitats, because responses could be species specific.

Our results have improved the understanding of the consequences of WLFs on littoral habitats, and the link between fish assemblages and habitats of the littoral zone of reservoirs. We are aware that the results of this type of approach can be highly dependent on the fish composition and natural diversity of the habitats in the littoral area of the studied reservoirs. However, our robust statistical method allows the demonstration of clear results for hypothesizing the consequences of water-level fluctuation on ecological processes able to impact ecosystem functioning.

Considering the observations of different fish-habitat relationships according to water level, an impact of water level management is expected on the biotic interactions occurring in the littoral area. These interactions can be particularly high in spring and summer when fish density in the littoral zone is the highest (Degiorgi \& Grandmottet 1993) with juveniles representing available prey. This suggests the maintenance of a high water level during these key periods so as to not negatively influence fish-habitat interactions.

\section{Acknowledgements}

We warmly thank T. Peroux and all the field staff from Irstea Aix-en-Provence for their assistance in the field. Our thanks are also extended to Electricite De France, which manages the Treignac hydroelectric dam and the associated Bariousses reservoir.

\section{References}

Beauchamp, D.A., Byron, E.R. \& Wurtsbaugh, W.A., 1994: Summer Habitat Use by Littoral-Zone Fishes in Lake Tahoe and the Effects of Shoreline Structures. - North American Journal of Fisheries Management 14: 385-394.

Brauns, M., Garcia, X. F. \& Pusch, M. T., 2008: Potential effects of water-level fluctuations on littoral invertebrates in lowland lakes. - Hydrobiologia 613: 5-12.

Broadmeadow, S. B., Jones, J. G., Langford, T. E. L., Shaw, P. J. \& Nisbet, T. R., 2010: The influence of riparian shade on lowland stream water temperatures in southern England and their viability for brown trout. - River Research and Applications 27: $226-237$.

Brosse, S., Grossman, G. D. \& Lek, S., 2007: Fish assemblage patterns in the littoral zone of a European reservoir. - Freshwater Biology 52: 448-458.

Cailleux, A. \& Tricart, J., 1959: Tome 1 - Initiation à l'étude des sables et des galets; Tome 2 - Valeurs numériques, morphométrie des sables ; Tome 3 - Valeurs numériques, galets, granulométrie, morphométrie et nature des sables. - Centre de documentation universitaire, Paris. 
Degiorgi, F. \& Grandmottet, J. P., 1993: Relations entre la topographie aquatique et l'organisation spatiale de l'ichtyofaune lacustre : définition des modalités spatiales d'une stratégie de prélèvement reproductible. - Bulletin Français de Pêche et de Pisciculture 329: 199-220.

Dembski, S., Masson, G., Wagner, P. \& Pihan, J. C., 2008: Habitat use by YOY in the littoral zone of an artificially heated reservoir. - International Review of Hydrobiology 93: 243-255.

Doledec, S. \& Chessel, D., 1994: Co-Inertia analysis: An alternative method for studying species-environment relationships. - Freshwater Biology 31: 277-294.

Dray, S., Chessel, D. \& Thioulouse, J., 2003: Co-inertia analysis and the linking of ecological data tables. - Ecology $\mathbf{8 4}$ : 3078-3089.

Dray, S., Dufour, A. B. \& Chessel, D., 2007: The ade4 packageII: Two-table and K-table methods. $-\mathrm{R}$. News 7: 47-52.

Eklöv, P., 1997: Effects of habitat complexity and prey abundance on the spatial and temporal distribution of perch (Perca fluviatilis) and pike (Esox lucius). - Canadian Journal of Fisheries and Aquatic Sciences 54: 1520-1531.

Emmrich, M., Pedron, S., Brucet, S., Winfield, I. J., Jeppesen, E., Volta, P., Argillier, C., Lauridsen, T. L., Holmgren, K., Hesthagen, T. \& Mehner, T., 2014: Geographical patterns in the body-size structure of European lake fish assemblages along abiotic and biotic gradients. - Journal of Biogeography 41: 2221-2233.

European Union, 2000: Directive 2000/60/EC of the European Parliament and of the Council establishing a framework for the community action in the field of water policy. - Off. J. Eur. Commun. (eds), pp. 1-72.

Falke, J. A. \& Gido, K. B., 2006: Spatial effects of reservoirs on fish assemblages in great plains streams in Kansas, USA. River Research and Applications 22: 55-68.

Fischer, P. \& Ohl, U., 2005: Effects of water-level fluctuations on the littoral benthic fish community in lakes: a mesocosm experiment. - Behavioral Ecology 16: 741-746.

Freedman, J. A., Lorson, B. D., Taylor, R. B., Carline, R. F. \& Stauffer, J. R. jr 2014: River of the dammed: longitudinal changes in fish assemblages in response to dams. - Hydrobiologia 727: 19-33.

Gafny, S. \& Gasith, A., 1999: Spatially and temporally sporadic appearance of macrophytes in the littoral zone of Lake Kinneret, Israel: taking advantage of a window of opportunity. - Aquatic Botany 62: 249-267.

Gafny, S., Gasith, A. \& Goren, M., 1992: Effect of water level fluctuation on shore spawning of Mirogrex terraesanctae (Steinitz), (Cyprinidae) in lake Kinneret, Israel. - Journal of Fish Biology 41: 863-871.

Gasith, A. \& Gafny, S., 1990: Effects of water level fluctuation on the structure and function of the littoral zone. - In: Tilzer, M. M. \& Serruya, C. (eds): Large Lakes: Ecological Structure and Function. - Springer, Berlin Heidelberg, Berlin, pp. 156-171.

Gasith, A. \& Gafny, S., 1998: Importance of physical structure in lakes: the case study of Lake Kinneret and general implications - In: Jeppesen, E., Sondergaard, M.A., Sondergaard, M. O. \& Christoffersen, K. (eds): The structuring role of submerged macrophytes in lakes. - Springer, Berlin, pp. 332-338.

Gelwick, F. P. \& Matthews, W. J., 1990: Temporal and spatial patterns in littoral-zone fish assemblages of a reservoir (lake Texoma, Oklahoma-Texas, USA). - Environmental Biology of Fishes 27: 107-120.
Heo, M. \& Gabriel, K. R., 1994: A permutation test of association between configurations by means of the RV coefficient. - Communications in Statistics - Simulation and Computation 27: 843-856.

Hill, M. O. \& Smith, A. J. E., 1976: Principal Component Analysis of taxonomic data with multistate discrete characters. Taxon 25: 249-255.

Hudon, C., 1997: Impact of water level fluctuations on St. Lawrence River aquatic vegetation. - Canadian Journal of Fisheries and Aquatic Sciences 54: 2853-2865.

Jager, H. I. \& Smith, B. T., 2008: Sustainable reservoir operation: Can we generate hydropower and preserve ecosystem values? - River Research and Applications 24: 340-352.

James, G. D. \& Graynoth, E., 2002: Influence of fluctuating lake levels and water clarity on trout populations in littoral zones of New Zealand alpine lakes. - New Zealand Journal of Marine and Freshwater Research 36: 39-52.

Kahl, U., Hulsmann, S., Radke, R. J. \& Benndorf, J., 2008: The impact of water level fluctuations on the year class strength of roach: Implications for fish stock management. - Limnologica 38: 258-268.

Keast, A., 1985: The piscivore feeding guild of fishes in small fresh-water ecosystems. - Environmental Biology of Fishes 12: 119-129.

Lavit, C., Escoufier, Y., Sabatier, R. \& Traissac, P., 1994: The ACT (STATIS method). - Computational Statistics \& Data Analysis 18: 97-119.

Leira, M. \& Cantonati, M., 2008: Effects of water-level fluctuations on lakes: an annotated bibliography. - Hydrobiologia 613: $171-184$.

Meerhoff, M., Iglesias, C., De Mello, F. T., Clemente, J. M., Jensen, E., Lauridsen, T. L. \& Jeppesen, E., 2007: Effects of habitat complexity on community structure and predator avoidance behaviour of littoral zooplankton in temperate versus subtropical shallow lakes. - Freshwater Biology 52: 1009-1021.

Midwood, J. D. \& Chow-Fraser, P., 2012: Changes in aquatic vegetation and fish communities following 5 years of sustained low water levels in coastal marshes of eastern Georgian Bay, Lake Huron. - Global Change Biology 18: 93-105.

Nilsson, C., Reidy, C.A., Dynesius, M. \& Revenga, C., 2005: Fragmentation and flow regulation of the world's large river systems. - Science 308: 405-408.

Ostrovsky, I. \& Walline, P., 2000: Multiannual changes in the pelagic fish Acanthobrama terraesanctae in Lake Kinneret (Israel) in relation to food sources. - Verhandlungen des Internationalen Vereins der Limnologie 27: 2090-2094.

Paller, M.H., 1997: Recovery of a reservoir fish community from drawdown related impacts. - North American Journal of Fisheries Management 17: 726-733.

Pierce, C. L., Rasmussen, J. B. \& Leggett, W. C., 1993: Littoral fish communities in Southern Quebec lakes - Relationships with limnological and prey resource variables. - Canadian Journal of Fisheries and Aquatic Sciences 51: 1128-1138.

R. Development Core Team, 2008: R: a language and environment for statistical computing. - R. Foundation for Statistical Computing, Vienna.

Robert, P. \& Escoufier, Y., 1976: A unifying tool for linear multivariate statistical methods: The RV-coefficient. - Applied Statistics 25: 227-265.

Rossier, O., 1995: Spatial and temporal separation of littoral zone fishes of Lake Geneva (Switzerland-France). - Hydrobiologia 300/301: 321-327. 
Rozas, L. P. \& Odum, W. E., 1988: Occupation of submerged aquatic vegetation by fishes - testing the roles of food and refuge. - Oecologia 77: 101-106.

Savino, J. F. \& Stein, R. A., 1989: Behavior of fish predators and their prey - habitat choice between open water and dense vegetation. - Environmental Biology of Fishes 24: 287-293.

Schmieder, K., 2004: European lake shores in danger - concepts for a sustainable development. - Limnologica 34: 3-14.

Southwood, T. R. E., 1977: Habitat, templet for ecological strategies? - Journal of Animal Ecology 46: 337-365.

Sutela, T. \& Vehanen, T., 2008: Effects of water-level regulation on the nearshore fish community in boreal lakes. - Hydrobiologia 613: 13-20.

Townsend, C. R. \& Hildrew, A. G., 1994: Species traits in relation to a habitat templet for river systems. - Freshwater Biology 31: 265-275.

Wantzen, K. M., Rothhaupt, K. O., Mortl, M., Cantonati, M., Laszlo, G. T. \& Fischer, P., 2008: Ecological effects of waterlevel fluctuations in lakes: an urgent issue. - Hydrobiologia 613: $1-4$.

Webb, P. W., 2008: The Impact of Changes in Water Level and Human Development on Forage Fish Assemblages in Great Lakes Coastal Marshes. - Journal of Great Lakes Research 34: $615-630$.
Werner, E. E., Hall, D. J., Laughlin, D. R., Wagner, D. J., Wilsmann, L.A. \& Funk, F. C., 1977: Habitat partitioning in a freshwater fish community. - Journal of the Fisheries Research Board of Canada 34: 360-370.

Werner, E. E., Gilliam, J.F., Hall, D. J. \& Mittelbach, G. G., 1983: An experimental test of the effects of predation risk on habitat use in fish. - Ecology 64: 1540-1548.

Werner, E. E., Mittelbach, G. G., Hall, D. J. \& Gilliam, J. F., 1983: Experimental tests of optimal habitat use in fish: the role of relative habitat profitability. - Ecology 64: 1525-153.

Wetzel, R. G., 1990: Reservoir ecosystems: conclusions and speculations. - In: Thornton, K. W., Kimmel, B. L. \& Payne, F.E. (eds): Reservoir limnology: ecological perspective. John Wiley \& Sons, Inc., New York, pp. 227-238.

World-Commission-on-Dams, 2000: Dams and DevelopmentA new framework for decision-making. - Earthscan Publications Ltd, London and Sterling, VA, pp. 1-356.

Yang, S. R., Gao, X., Li, M. Z., Ma, B. S. \& Liu, H. Z., 2012: Interannual variations of the fish assemblage in the transitional zone of the Three Gorges Reservoir: persistence and stability. - Environmental Biology of Fishes 93: 295-304.

Zohary, T. \& Ostrovsky, I., 2011: Ecological impacts of excessive water level fluctuations in stratified freshwater lakes. Inland Waters 1: 47-59. 